\title{
The Effect of School Leadership and Management on Teacher Performance in Cluster IV of East Baturaja
}

\author{
Natri Kirana ${ }^{1 *}$, Happy Fitria ${ }^{2}$, Yessi Fitriani ${ }^{2}$ \\ ${ }^{1} S D$ Negeri 10 OKU, South of Sumatera, Indonesia \\ ${ }^{2}$ Universitas PGRI Palembang, Indonesia \\ *Corresponding author. Email: natrikirana400@gmail.com
}

\begin{abstract}
This research aimed at finding out the effect of school leadership and management on teacher performance in cluster IV of East Baturaja. The hypotheses in this study are: (1) there is an effect of leadership on teacher performance; (2) there is an effect of school management on teacher performance, and (3) there is an effect of leadership and school management simultaneously on teacher performance. This research uses descriptive quantitative method with descriptive statistical techniques, simple correlation and regression analysis, as well as correlation analysis and multiple regression. The population in this study were all school teachers in cluster IV of east Baturaja in Ogan Komering Ulu Regency, totaling 60 people. The results of the study are: (1) there is the effect between leadership on teacher performance, (2) there is the effect of between school management on teacher performance, (3) leadership and school management together have the effect of on teacher performance. This is indicated by the coefficient of determination of $82.8 \%$.
\end{abstract}

Keywords: Leadership, School Management, Teacher Performance

\section{INTRODUCTION}

In its position to improve the success of education, the importance of teacher performance variables is important, so it is absolutely crucial to preserve and aim for high performance teachers. It is important to immediately address what factors affect teacher performance improvement so that the problem of improving the quality of education, particularly SD Negeri in cluster IV, East Baturaja, can be realized. According to Kristiawan et al [1];[2], optimizing student capacity, human resource preparation, developing student character values, digital-based learning facilities and technology, effective curriculum and policies in education are some of the solutions that must be implemented in the world of education.

Teachers are the main key to enhancing the quality of education, and if its execution is carried out by educators whose professionalism can be depended upon, an important criterion for the realization of quality education is. As long as lecturers and teachers do not want to change, they are not adaptive and anticipatory to change, the world of education will not undergo any change. Teachers' less-than-optimal performance in schools is not entirely due to a lack of capacity on their part. Many factors, both external and internal, influence teacher success [3]. Leadership is the capacity to control individuals or organizations in order to accomplish goals [4]. The level of effectiveness of the principal's leadership and management, its impact on enhancing the performance of teachers and employees who engage in growing student achievement towards quality development based on the mutually agreed vision and purpose of the school, is one of the key aspects that is closely linked to the performance of school principals.

The Principal must be able to practice creativity, lead all participants and the school as an educational institution to change their minds, develop their vision and purpose by using the strengths, expertise and abilities of its members [5]. The style of leadership embraced by the Principal would contribute to the results and success of the Principal in guiding and executing the school education process [6]. Principals must be capable of overseeing schools and must be equipped to do so [7].

As the educational institution's head, the principal is in charge of all educational activities at the school [8]. The position of the principal as a leader with a style of leadership must be able to influence other people or employees [9]. Leaders must be able to make accurate and timely decisions based on proper and mature [10]. With the proper functioning of leadership management, it is believed that the institutions they lead will experience development and improvement in the quality of education [11]. The Principal, as a leader, becomes a promoter of the school community, especially teachers, 
whose guidance is aimed at achieving the school's vision, mission, and objectives [12].

Teacher efficiency is the capacity of the teacher to execute their activities in the form of teaching preparation, teaching execution and interpersonal relationships, as well as being able to use it as a consideration for a leader to improve job productivity and calculations to grow the organization to achieve organizational objectives [13]. Many factors affect teacher efficiency, one of which is the environment that exists in a work unit, in this case called the organization [14]. Kartini et al note that there is a major influence on the success of teachers between principal leadership, academic supervision and professional competence at the same time [15]. School management is "special abilities and skills to carry out an activity either with other people or through other people in achieving organizational goals" [16]

The success of schools in raising educational standards is a shared responsibility of teachers and school principals [17]. The researcher is interested in offering the title "The Effect of School Leadership and Management on Teacher Performance in Cluster IV of East Baturaja." based on the context description above. The aim of the study: (1) is to decide and explain whether there is an impact of leadership on teacher performance in Cluster IV, East Baturaja, in accordance with the problem formulation; (2) to decide and explain whether school management has an effect on the performance of teachers in Cluster IV, East Baturaja, and (3) in cluster IV, East Baturaja, to assess and explain whether there is an effect of school leadership and management on teacher performance if performed simultaneously.

\section{METHODS}

This research uses a quantitative descriptive approach to partially see the impact between the current variables [4]. The quantitative research variables evaluated in this study consisted of leadership of school management $\left(\mathrm{X}_{1}\right)$, teacher efficiency $(\mathrm{Y})$, then quantitative analysis analyzed and processed all the data collected. To obtain and draw conclusions from test findings, the SPSS (Statistical Kit for Service Solution) software assistance is used in data collection and calculations. All teachers in Clustur IV, East Baturaja, with a total of 60 individuals as the unit of research distributed in Cluster IV, East Baturaja, were in the population of this report. Simple random sampling was the sampling approach used in this analysis, which is how a sample of 60 teachers could be taken. The research site is located in elementary schools in Cluster IV of East Baturaja. This study was carried out in schools comprised of SD Negeri 5 OKU, SD Negeri 6 OKU, SD Negeri 7 OKU, SD Negeri 9 OKU, SD Negeri 9 OKU, and SD Negeri 10 OKU in Cluster IV of the East Baturaja. The method of data collection is carried out by observation and questionnaires (questionnaire).

\section{RESULTS AND DISCUSSION}

The data is then analyzed in the form of descriptive statistical analysis, based on the study data collected. This study was carried out in the Elementary School Cluster IV, East Baturaja to evaluate the definition of the variable leadership style $\left(\mathrm{X}_{1}\right)$ and school management $\left(\mathrm{X}_{2}\right)$ on teacher performance $(\mathrm{Y})$. The results of the research study showed that the leadership carried out by teachers in the Cluster IV elementary school, East Baturaja in 2020 was in the positive category because it was in the 25 and 41.7 percent frequency interval of 85-92. The results of data analysis on hypothesis testing show that there is an impact on teacher performance in the primary schools of Cluster IV, East Baturaja in 2020 between school management, which is in a sufficient category because it is located at the 88-83 interval with a frequency of 27 and 45.0 percent. The data analysis results show that the performance of teachers in Cluster IV, East Baturaja primary schools in 2020 is included in the Positive group because it is in the 87-93 interval with a frequency of 24 and $40.0 \%$. Based on the outcomes of the discussion above, it is clear that there is an impact on teacher success between leadership and school management.

\section{CONCLUSION}

The findings of this analysis can be inferred as follows, based on the results of the above discussion: a) leadership has an impact on the success of teachers. This conclusion suggests that the higher the effectiveness of leadership, the higher the performance of the instructor; b) management has an impact on the success of students. This inference suggests that the higher the leadership of the school, the greater the success of the teacher, and 3) teacher success is influenced collectively by leadership and school management.

It can be interpreted on the basis of the research results that teacher performance would be strong, successful leadership and sponsored by school leadership so that it has an impact on teacher performance. With leadership that can inspire teachers to provide school management, teacher performance can be optimized to always demonstrate their best performance in achieving school objectives. This research thus confirms the direct impact of the relationship between school leadership and management on the performance of teachers.

\section{ACKNOWLEDGMENT}

Our deepest gratitude goes to Teachers in SD Negeri 10 OKU, Chancellor of Palembang PGRI University, 
Director of the Postgraduate Program of PGRI Palembang University and the Education Management Study Program of PGRI Palembang University, who have supported us in doing this extraordinary thing. This project is funded independently. We also want to thank our Education Management friends who helped us a lot in a short time frame to complete this project.

\section{REFERENCES}

[1] Kristiawan, M. (2015). A Model of Educational Character in High School Al-Istiqamah Simpang Empat, West Pasaman, West Sumatera. Research Journal of Education, 1(2), 15-20.

[2] Kristiawan, M., Nizarani., \& Syamsidar. (2019). Role of School on Forming Character of Generation Through Entrepreneurial Skills. International Journal of Scientific \& Technology Research, 8(10).

[3] Maryati, E., Fitria, H., \& Rohana, R. (2020). The Influence of Principal's Leadership Style and Organizational Culture on Teacher's Performance. Journal of Social Work and Science Education, 1(2), 127-139. Retrieved from https://ejournal.karinosseff.org/index.php/jswse/arti cle/view/38

[4] Sugiyono. (2014). Qualitative and $R \& D$ Quantitative Analysis Approaches. Alfabeta: Bandung.

[5] Andriani, S., Kesumawati, N., \& Kristiawan, M. (2018). The Influence of the Transformational Leadership and Work Motivation on Teachers Performance. International Journal of Scientific \& Technology Research, 7(7).

[6] Astuti, R. W., Fitria, H., \& Rohana, R. (2020). The Influence of Leadership Styles and Work Motivation on Teacher's Performance. Journal of Social Work and Science Education, 1(2), 105-114. Retrieved from https://ejournal.karinosseff.org/index.php/jswse/arti cle/view/33

[7] Meidiana., Ahmad, S., \& Destiniar. (2020). Pengaruh Kompetensi Manajerial Kepala Sekolah dan Supervisi Akademik Terhadap Kinerja Guru [Effect of Principal Managerial Competence and Academic Supervision on Teacher Performance]. Jurnal Manajemen, Kepemimpinan dan Supervisi Pendidikan 5(2), Juli-Desember.

[8] Agustina, M., Kristiawan, M., \& Tobari. (2021). The Influence of Principal's Leadership and School's Climate on The Work Productivity of Vocational Pharmacy Teachers in Indonesia. International Journal of Educational Review 3(1), 63-76.

[9] Asvio, N., Yamin, M., \& Risnita. (2019). Influence of Leadership Style, Emotional Intelligence and
Job Satisfaction toward Organizational Commitment (Survey at SMA Muhammadiyah South Sumatera). International Journal of Scientific \& Technology Research 8 (8).

[10] Mukhtar, Yamin, M., \& Nurzen, S. S. (2020). The Influence of Academic Culture, Management Knowledge and Interpersonal Communication on Decision Making by the Head of Private Islamic Colleges in Jambi Province. International Journal of Progressive Sciences and Technologies (IJPSAT) Vol. 23 No. 2 November 2020, pp. 09-19.

[11] Hendriyadi, Ritonga, A. H., \& Us, K. A. (2020). Management Leadership in Improving the Quality of Graduates of Private Islamic Religious Colleges in Jambi Province. International Journal of Progressive Sciences and Technologies (IJPSAT) Vol. 23 No. 2 November 2020, pp. 42-51 Retrieved from $\quad$ https://ijpsat.ijshtjournals.org/index.php/ijpsat/article/view/2308

[12] Suratman, S., Arafat, Y., \& Eddy, S. (2020). The Influence of Principal's Leadership and Teacher's Competence toward Teacher's Performance in Indonesia. Journal of Social Work and Science Education, 1(2), 96-104. Retrieved from https://ejournal.karinosseff.org/index.php/jswse/arti cle/view/32

[13] Majid. (2016). Teacher Performance Professional. Jakarta: Media Prenada.

[14] Budiyono, Lian, B., \& Fitria, H. (2020). The Influence of Principal Supervision and Organizational Climate toward Teacher's Performance. Electronic Research Journal of Social Sciences and Humanities Vol 2: Issue II, Apr - Jun 2020.

[15] Kartini, D., Kristiawan, M., \& Fitria, H. (2020). The Influence of Principal's Leadership, Academic Supervision, and Professional Competence toward Teachers' Performance. Education and Training for Strengthening Principal to Effective Schools. International Journal of Progressive Sciences and Technologies (IJPSAT), 20(1).

[16] Sudjana. (2014). Management of out-of-school education training services. Bandung: Falah Manufacturing.

[17] Khasanah, U., Kristiawan, M., \& Tobari. (2019). The Implementation of Principals' Academic Supervision in Improving Teachers' Professionalism in the State Primary Schools. International Journal of Scientific \& Technology Research, 8(8). 